УДК 902/908: $904: 621$

DOI: https://doi.org/10.33782/eminak2021.1(33).495

\title{
КЕРАМІЧНИЙ КОМПЛЕКС БОРИСФЕНА ПЕРІОДУ РАННЬОЇ АРХАЇКИ (ЗА МАТЕРІАЛАМИ КОЛЕКЦІЇ В.В. ЛАПІНА)
}

\author{
Надія Гаврилюк \\ Інститут археології НАН України (Київ, Україна) \\ e-mail: gavrylyuk_na@ukr.net \\ ORCID: https://orcid.org/0000-0002-2369-5701
}

У статті йдеться про керамічний комплекс перших поселенців на о. Березань і визначення ролі ліпного посуду у ньому. Вирішується питання кому належала ліпна кераміка 3 матеріалів найраніших шарів Борисфену - варварам чи грекам. Джерельною базою статті є матеріал з колекції В.В. Лапіна. Показані перспективи використання статистичних методів у вивченні масового керамічного матеріалу. Показана різниця між керамічними комплексами об'єктів, котрі були створені «до стихійного лиха» та «після стихійного лиха» у межах другої половина VII - початку VI cm. до н.е.

Ключові слова: Березань, Борисфен, ліпна кераміка, датування, греки, варвари

Проблемою, що розглядається, є етнічна приналежність населення, що створювало ліпну кераміку для перших мешканців античного Борисфену. Керамічний побутовий комплекс перших поселенців на о. Березань, як і інших поселень Північного Причорномор'я античної доби, прийнято вважати одним з етноіндикаторів населення.

В.В. Лапін ${ }^{1}$, дослідник, матеріали якого з розкопок 1960-1980 рр. стали джерельною базою для написання статті, бачив у ліпному посуді органічний елемент грецької матеріальної культури і взагалі заперечував поширену в науці думку про належність скіфам ліпної кераміки, котру знаходять у культурних шарах античних поселень Північного Причорномор'я і, саме, на Березані. На жаль, створена ним дуже детальна типологія ліпного посуду Березані й аргументація на користь визнання її грецькою так і залишилася ненадрукованою22.

Інша, «варварська» точка зору, що була висунута у 1950-х рр., була підтримана та додатково аргументована у роботах К.К. Марченка ${ }^{3}$. Ним були досить ретельно вивчені деякі технологічні аспекти виробництва ліпного посуду Березані й інших поселень Нижнього Побужжя. К.К. Марченком встановлено, що посуд пізньоархаїчного часу виготовлений з місцевих жирних карбонатних і безкарбонатних глин сірого кольору. Вони погано перемішані та після обпалу дають неоднорідну порожнисту структуру. Мінералогічний склад глин у більшості випадків однаковий. Дуже рідко зустрічаються відхилення, які дозволяють припустити, що окремі екземпляри лощеного столового посуду могли бути виготовленими за межами регіону. На думку К.К. Марченка майже весь ліпний посуд архаїчного часу обпалювався у

\footnotetext{
1 Лапин В.В. Греческая колонизация Северного Причерноморья. Киев, 1966. 236 с.

2 Лапин В.В. Березань и проблемы генезиса античной северопричерноморской цивилизации // Науковий архів Інституту археології НАН України. 1978. Ф. 24. 438 с.

3 Марченко К.К. Лепная керамика // Культура населения Ольвии и ее округи в архаическое время. Киев, 1986. С. 104-115.
} 
вогнищах чи ямах. За функціональним призначенням ліпний посуд Березані був розділений К.К. Марченком на три групи - кухонний, столовий і тару, у межах яких виділено види (горщики, корчаги, миски й ін.). Види розподілені на типи. Основна типоутворююча ознака - форма горла посудини. За формою тулубу виділяються варіанти.

На початку XXI ст. з'явилася публікація колекції ліпного посуду з розкопок експедиції Державного Ермітажу. Каталог цієї колекції вперше представляє не тільки парадний і столовий посуд цього поселення, але декілька ліпних посудин. Однак, стаття, присвячена публікації ліпного посуду4, досить проблемна і з точки зору методики дослідження ліпного посуду, і з точки зору того, як вирішується у ній питання взаємовідношень між греками-переселенцями та місцевим населенням. Остаточно ця проблема визначилася у колективній монографії наших петербурзьких колег. Аргументація щодо питання наявності варварського населення у степовій зоні Північного Причорномор'я зводиться до того, що переселенці опинилися в умовах terre deserta та відсутності тут кочовиків, і що степовий коридор «естественным образом становился наиболее удобной и легкопроходимой дорогой, улучшавшей связь между жителями различных регионов». Далі йде досить побіжна характеристика дійсно потужного пласту «местной земледельческо-скотоводческой культуры», що мешкала у лісостепу і твердження про те, що «...в середине второй половине VII в. до н.э., т.е. в момент выведения сюда первых эллинских колоний, прибрежная полоса района должна была находиться под самым действенным контролем со стороны обитателей лесостепной зоны»5.

Оскільки найдавнішим поселенням на території Північного Причорномор'я $\epsilon$ поселення на о. Березань, а ліпний посуд з цього поселення є чи не єдиним аргументом щодо присутності у складі перших грецьких поселень місцевого населення, саме колекція цього поселення зазнала сумлінного дослідження С.М. Сенаторовим. Базою для аргументації щодо присутності варварського лісостепового населення стали два, нібито жаботинських, черепка та спостереження про зникнення горщиків з «розчленованими валиками та проколами». Раніше автор стверджував, що такий орнамент характерний для «банковидного чорнолощеного горщика (тип 2, табл. 30,8; табл. 7: 6; та 11: 21)»6, (чорнолощений посуд неоднорідний за походженням і «розтягнутий» у досить широких хронологічних межах). Здається, це недостатня аргументація для таких узагальнень. Гіпотеза, висунута В.В. Лапіним про можливість виготовлення та використання ліпного посуду першими грецькими переселенцями, взагалі не обговорюється.

Для вирішенні зазначеної проблеми спробуємо змінити методику дослідження керамічного матеріалу, залучаючи до процесу його вивчення весь масовий матеріал, розглядаючи його у широкому хронологічному діапазоні. Доцільно також змінити алгоритм подання матеріалів: крім звичної для археологів класифікації й опису матеріалів, необхідно звернути увагу на весь побутовий (без амфорної тари) керамічний комплекс поселення, зробити кількісну його оцінку кожної керамічної

\footnotetext{
4 Сенаторов С.Н. Лепная керамика поселения на острове Березань: из раскопок Государственного Эрмитажа 1963-1991 гг. // С.Л. Соловьев (ред.). Борисфен-Березань. Археологическая коллекция Эрмитажа. Санкт-Петербург, 2005. Т. 1. С. 174-350.

5 Греки и варвары Северного Причерноморья в скифскую эпоху / ред. К.К. Марченко. СанктПетербург, 2005, с. 50-51.

6 Сенаторов С.Н. Лепная керамика поселения на острове Березань... С. 174-350.
} 
групи та шляхом порівняння певних керамічних груп прослідкувати особливості розвитку кожної групи.

Отже, мета роботи: визначити набір посуду останньої чверті VII - першої половини VI ст. до н.е., виявити співвідношення основних груп кераміки у господарстві перших мешканців поселення, окреслити видовий набір ліпного посуду першого архаїчного періоду, базуючись на датуванні розписного гончарного посуду з колекції В.В. Лапіна, запропонованої нещодавно7.

\section{Локалізація архаїчних об'єктів Борисфена та їх характеристика.}

Використовуються матеріали 3 розкопу «Основний» (сучасна назва - «0Східний»), локалізованого на східному узбережжі острова на мисі, що південніше місця причалу. Використовуються матеріали 7 напівземлянок і 7 господарських ям (табл. 1), котрі мають загальне датування другою половиною VII - першою половиною VI ст. до н.е.

Тут і далі використовується загальноприйнята періодизація поселення на о. Березань з останніми змінами. Отже, хронологічні межі представленого матеріалу відповідають першому періоду архаїки. Однак у польовій документації міститься більш детальний хронологічний розподіл матеріалів, що виник під час польових спостережень В.В. Лапіна. Саме цим пояснюється поява підперіодів, котрі використовуються у статті: «до стихійного лиха»; друга половина VII - початок VI ст. до н.е. (табл. 1). Проводиться порівняння керамічного комплексу з житлових і побутових споруд перших поселенців, які з'явилися на о. Березань «до стихійного лиха» і після нього.

Табл. 1. Список досліджуваних об'єктів

\begin{tabular}{|c|c|c|c|c|c|c|c|}
\hline Об’єкт & $\begin{array}{c}\text { Дата } \\
\text { (роки до н.е.) }\end{array}$ & № & Рік & Квадрат & $\begin{array}{c}\text { Спи- } \\
\text { сок }\end{array}$ & Розміри у м & $\begin{array}{c}\text { Глибина } \\
\text { (материк) }\end{array}$ \\
\hline \multicolumn{8}{|c|}{ Напівземлянки (НПЗ) та господарські ями (ГЯ) «до стихійного лиха» } \\
\hline НПЗ & $610 / 590-570$ & 58 & 1975 & $147-148$ & $1 \mathrm{i} 2$ & $\begin{array}{c}3,6-1,7 ; 2 \times 1,8 \\
\text { (тамбур) }\end{array}$ & 1,32 \\
\hline НПЗ & $590-570$ & 70 & 1977 & $149 \mathrm{a}$ & 15 & $\begin{array}{c}2,5-2,6,0,9- \\
\text { тамбур } \\
\end{array}$ & $0,25-0,30$ \\
\hline НПЗ & $610 / 590-575$ & 71 & 1977 & $149 a-150 a$ & 22 & 3,4 & 0,25 \\
\hline НПЗ & $610 / 600-550$ & 72 & 1977 & $150-151 a$ & 20 & $3,4 \times ?$ & 0,25 \\
\hline ГЯ & $625-575$ & бн & 1975 & 149 & & & 1,8 \\
\hline ГЯ & $625-600$ & 176 & 1975 & 233 & 22,21 & $1,3-1,4$ & 1,05 \\
\hline \multicolumn{8}{|c|}{ Друга половина VII - початок VI cm. до н.е. } \\
\hline НПЗ & $630-610 / 600$ & 59 & 1975 & $146 a$ & 32 & $5,2 \times 3$ & 1,2 \\
\hline НПЗ & $610-590$ & 65 & 1976 & 227 & 21 & $3 \times 2,75$ & $1,95-2$ \\
\hline НПЗ & $600 / 590-550$ & $65 a$ & 1976 & 227 & 20 & $3,7 \times 2,8$ & $1-1,2$ \\
\hline ГЯ & $600 / 599-575$ & 1 & 1960 & басейн & $\begin{array}{l}37,38, \\
63-65 \\
\end{array}$ & & 3,5 \\
\hline ГЯ & $590 / 580-570$ & 52 & 1964 & 93 & 47 & & \\
\hline ГЯ & $625-575$ & 162 & 1974 & 45 & 68 & 1,85 & 2,05 \\
\hline ГЯ & $590 / 580-570$ & 169 & 1975 & 147 & 6 & 0,88 & 0,92 \\
\hline ГЯ & $625-580$ & 172 & 1975 & $142-147$ & 5 & 1,2 & 2,2 \\
\hline
\end{tabular}

\footnotetext{
7 Буйских А.В. Архаическая расписная керамика из Борисфена. Киев, 2019. 392 с.
} 


\section{«До стихійного лиха», або керамічний комплекс перших мешканців посе- лення на о. Березань.}

Більшість об’єктів локалізувалися на південній ділянці розкопу «ОсновнийСхідний», де у 1975 р. В.В. Лапін помітив «следы перемещения слоев. По-видимому, тут существовала в древности долина Березанского лимана, уничтоженная размывами»8. Роботи 1975-1977 pр. були зосереджені у квадратах, котрі знаходилися на береговій лінії. За стратиграфічними та геологічними спостереженнями підтвердилася гіпотеза про те, що досліджувана ділянка була схилом долини Березанського лиману, розмитим підйомом рівня води у Чорному морі, доказами чого були лесові запливи у заповненні деяких об’єктів 9 . У польових звітах В.В. Лапіним описана низка напівземлянок, котрі він відніс до початку життя на поселенні ${ }^{10}$. Отже, джерелом для опису побутового керамічного посуду перших поселенців на о. Березань є матеріали чотирьох напівземлянок округлої з тамбуром (58; 70), круглої (71), або овальної без тамбура (72) форм і двох господарських ям: 176 і без номера (б/н) 1975 р. Короткий опис споруд із датуванням terminus post quem надано у табл. 1 .

Описані об’єкти представлені напівземлянками та господарськими ямами. Якщо форма ям упродовж визначеного вище часу залишається незмінною, то форма напівземлянок замінюється - овальні напівземлянки з тамбуром, або без нього, змінюються на прямокутні.

Асортимент кераміки складений за даними польових списків, польового опису та колекції № 1446, котра зберігається у фондах Інституту археології НАН України. Якісні зміни у складі колекції простежуються на прикладах основних керамічних груп, характерних для поселення на о. Березань: розписного (парадного) посуду, ліпного та гончарного кухонного (кухонного), червоноглиняного та сіроглиняного (столового) та товстостінного (господарського). Окремі групи посуду складають світильники та чорнолаковий посуд (табл. 2).

Заповнення напівземлянок першої групи прошаровані стерильними лесовими шарами. Тому мова йде, в основному, про найнижчі шари з невеликою кількістю знахідок. Для об'єктів початкового періоду «частка вивченості» керамічного матеріалу (співвідношення знахідок, занесених до польових списків і знахідок кераміки внесених до польових колекційних списків) коливається у межах від 8 до 16\%.

Найчастіше зустрічаються фрагменти розписної кераміки. Її відсоток у заповненні напівземлянок складає від 51,51\% (НПЗ 72) до 74,43\% (НП3 70) (рис. 1). Середній показник для напівземлянок періоду «до стихійного лиха»-60\% (табл. 2). Друге місце за кількістю займають фрагменти ліпного посуду - від 7,81\% (НПЗ 70) до 24,28\% (НП3 72) (рис. 1), середній показник - 16\% (табл. 2). Трохи менше використовувалось у перший період існування поселення червоноглиняного посуду (глечики, миски) - від 3,41\% (НПЗ 70) до 15,16\% (НПЗ 72) (рис. 1), у середньому -

\footnotetext{
8 Лапин В.В. Отчет о раскопках древнегреческого поселения на о. Березань в 1975 году (экспедиция Археологического музея АН УССР) // Науковий архів Інституту археології НАН України. 1975/114.

9 Лапин В.В. Отчет о раскопках древнегреческого поселения на о. Березань в 1976 году (экспедиция Археологического музея Института археологии АН УССР) // Науковий архів Інституту археології НАН України. 1976/116.

10 Лапин В.В. Отчет о раскопках древнегреческого поселения на острове Березань в 1977 году экспедицией Киевского государственного университета в 1977 году // Науковий архів Інституту археології НАН України. 1977/98.
} 
10\% від кераміки (табл. 2). У групу сіроглиняного посуду, за даними польових списків, входить і простий сіроглиняний, і сіроглиняний посуд з лощенням (глечики, миски). Його відсоток у колекції коливається від 3,84\% до (НПЗ 70) до 9,45\% (НП3 58), у середньому - 6\% (табл. 2). Фрагменти гончарного кухонного посуду (горщики з однією ручкою й округлим денцем, котрі мають аналогії серед мілетського посуду11) зустрічаються нечасто. Фрагменти такого посуду складають від 1,14\% (НПЗ 70) до 6,56\% (НПЗ 58), середній показник 2,9\% (табл. 2). Товстостінна кераміка, яку визначаються як господарська 12 і котра складається з червоноглиняних лутеріїв (мортаріїв), зустрічається у дуже невеликій кількості, але в усіх напівземлянках і тільки в одному випадку, - (НПЗ 72) зафіксовано фрагменти піфосів (рис. 1, табл. 2). Іноді у зазначених напівземлянках трапляються відкриті світильники (0,4\%). Фрагменти чорнолакового посуду (у середньому 3,4\%) походять переважно з верхніх прошарків напівземлянок (табл. 2).

Табл. 2. Керамічний комплекс напівземлянок, що виникли на о. Березань «до стихійного лиха»

\begin{tabular}{|l|c|c|c|c|c|c|c|c|c|}
\hline & $\begin{array}{c}\text { НПЗ- } \\
58\end{array}$ & $\%$ & $\begin{array}{c}\text { НПЗ- } \\
70\end{array}$ & $\%$ & $\begin{array}{c}\text { НП3- } \\
71\end{array}$ & $\%$ & $\begin{array}{c}\text { НП3- } \\
72\end{array}$ & $\%$ & $\begin{array}{c}\text { Середнє } \\
\text { число, \% }\end{array}$ \\
\hline Розписна & 224 & 58,79 & 524 & 74,43 & 382 & 55,28 & 615 & 51,51 & $\mathbf{6 0}$ \\
\hline Ліпна & 49 & 12,87 & 55 & 7,81 & 126 & 18,23 & 290 & 24,28 & $\mathbf{1 6}$ \\
\hline Червоноглиняна & 25 & 6,56 & 24 & 3,41 & 100 & 14,47 & 181 & 15,16 & $\mathbf{1 0}$ \\
\hline Сіроглиняна & 36 & 9,45 & 27 & 3,84 & 44 & 6,37 & 54 & 4,52 & $\mathbf{6}$ \\
\hline Кухонна & 25 & 6,56 & 8 & 1,14 & 14 & 2,03 & 31 & 2,6 & $\mathbf{2 , 9}$ \\
\hline Товстостінна & 5 & 1,31 & 1 & 0,14 & 12 & 1,74 & 17 & 1,42 & $\mathbf{1 , 2}$ \\
\hline Піфоси & 0 & 0 & 0 & 0 & 0 & 0 & 4 & 0,34 & $\mathbf{0 , 1}$ \\
\hline Світильники & 0 & 0 & 5 & 0,71 & 7 & 1,01 & 2 & 0,17 & $\mathbf{0 , 4}$ \\
\hline Чорнолакова & 17 & 4,46 & 60 & 8,52 & 6 & 0,87 & 0 & 0 & $\mathbf{3 , 4}$ \\
\hline & 381 & 100 & 704 & 100 & 691 & 100 & 1194 & 100 & \\
\hline
\end{tabular}

На основі стратиграфічних даних до групи об’єктів віднесено дві господарські ями - 176 та б/н 1975 року. Вони мали у перерізі грушоподібну форму та були заглиблені у материк (табл. 1). У порівнянні з напівземлянками, кількість керамічних груп суттєво змінюється - до прикладу - в ямі 176 їх п’ять. Кількісні показники по кожній групі посуду близькі до показників з напівземлянок. Так, парадний посуд представлений фрагментами розписних (69,88\%) посудин. Столовий посуд складається з сіроглиняних (лощених та нелощених) (6,02\%) і червоноглиняних $(8,43 \%)$ посудин, переважно глечиків і мисок. Кухонна кераміка - це фрагменти грубих гончарних горщиків $(4,82 \%)$ і ліпного посуду $(10,84 \%)$. Кількість ліпної кераміки, у порівнянні з гончарним кухонним посудом, більше у 2 рази (рис. 1).

Отже, основний набір перших мешканців поселення на о. Березань складався 3 розписного посуду, який переважав (близько 60\% побутового керамічного посуду). Вірогідно, більшість його йшла на перепродаж. Найранішою знахідкою з цієї

11 Чистов Д.Е., Ильина Ю.И., Щербакова О.Е. Кухонное оборудование и кухонная керамика архаического Березанского поселения // Клио. 2015. № 11 (107). С. 13-26; Gavrylyuk N. Greeks and Barbarians of the Northen Back Sea area during the Archaic perion (the end of the $7^{\text {th }} 6^{\text {th }}$ centuries BC) // Actuale archeologique ukrainienne: Olbia pontique, lelime et les Barbares. Lausanne, 2018. P. 12-18. 12 Чистов Д.Е., Ильина Ю.И., Щербакова О.Е. Кухонное оборудование и кухонная керамика... С. 14 
групи напівземлянок $є$ південно-іонійська ольпа зі смугами на придонній частині (1.320) з господарської ями 176, що датується 625-600 рр. до н.е. 3 напівземлянки 71 походить фрагмент поліхромної еолійської ойнохої (7.30), датованої 610/590575 гг. до н.е. ${ }^{13}$ Саме їх можна з великою мірою впевненості можна зв'язати з посудом, котрий використовувався першими колоністами у побуті.

Однак у матеріалах напівземлянок першої хронологічної групи переважали вироби північноіонійського виробництва, прикрашені у стилі LWG/NiA I. Це чаша 3 фризом (3.22) з напівземлянки 58, що датується рубежем VII-VI ст. - кінцем першої чверті VI ст. до н.е.; кратер (2.256) з напівземлянки 70, що датується 590/580570 р. до н.е. та дві ойнохої (2.37 і 2.47) з напівземлянки 71, що відносяться до 590/580-570 р. до н.е. Два іонійські киліки (4.117 і 4.120), з напівземлянки 72, датуються 610/600-550 и 610/600-540/530 р. до н.е. ${ }^{14}$. Зазначений посуд, у певній мірі, може вважатися побутовим, але й таким, що був взятий на обмін з варварами. Не випадково саме північноіонійська кераміка згадується серед імпортів, котрі 3 ранньоскіфського часу надходили до Більського ${ }^{15}$ та Немирівського городищ ${ }^{16}$.

Весь ліпний посуд, який займає друге місце за кількістю у побутовому керамічному наборі перших мешканців поселення на о. Березань (середній показник 16\%), виготовлений з одноманітної формувальної маси з крупними домішками дресви, котра на зламі черепка стає тришаровою: темно-сірий на зовнішній поверхні підстилає яскраво оранжевий, внутрішній - чорний, який на внутрішній поверхні посудини набуває темно-сірого кольору.

У колекції ліпного посуду з перших земляних споруд поселення переважають банкоподібні посудини (рис. 2). У них відігнуті вінця та чітко намічена шийка, котра підкреслюється масивним валиком. Валик орнаментується глибокими косими насічками (рис. 2,1) як на посудині 3 напівземлянки 58; косими защипами (рис. 2, 2) з напівземлянки 72, або пальцевими защипами з наколами (рис. 2, 3). Діаметри таких посудин від 12 до 18 см. Вони зустрічаються і в інших спорудах першого архаїчного періоду17. Банкоподібна посудина з ледь наміченою шийкою (АБ 77-328) з напівземлянки мала на шийці валик, але була орнаментована пальцевими відбитками на зрізі вінець (рис. 2,4). Фрагмент АБ 77-301 напівземлянки 72 мав пряме горло з різко відігнутим вінцем з широким відтягнутим валиком, орнаментованим пальцевими вдавленнями (рис. 2,5). Фрагмент банкоподібної посудини великих розмірів АБ 77-303 з напівземлянки 72 міг належати посудині зі скошеними до середини вінцями, оскільки масивний наліпний валик з пальцевими відбитками розміщувався на плічках посудини (рис. 2, 6).

Вважається, що банкоподібні форми вперше з'являються у кераміці культури

\footnotetext{
13 Буйских А.В. Архаическая расписная керамика... С. 41. 241, рис. 33; С. 145-146, 340, рис. 132; ${ }_{14}$ Ibid. С. $85,87,280$, рис. 72 ; С. 68,261 , рис. 53 ; С. 46,245 , рис. 37 ; С. 47 , 245, рис. 38 ; С. 116,304 , рис. 96.

15 Задников С.А. Торговые отношения Бельского городища с Березанью // Перипл: от Борисфена до Боспора. Материалы юбилейных конференций / Государственный Эрмитаж. Санкт-Петербург, 2017. C. 65-74.

16 Вахтина М.Ю. Греческая керамика из раскопок Немировского городища // Смирнова Г.И., Вахтина М.Ю., Кашуба М.Т., Старкова Е.Г. Городище Немиров на реке Южный Буг. Санкт-Петербург, 2018. C. 193-223.

17 Чистов Д.Е., Зуев В.Ю., Ильина Ю.И., Каспаров А.К., Новоселова Н.Ю. Материалы Березанской (Нижнебугской) античной археологической экспедиции // Исследование на о. Березань в 20052009 гг. Т. 2. Санкт-Петербург, 2012. С. 37, 38, 202, табл. 46, 1-4.
} 
Ноа. У некрополі Феріджеле вони складають 9\% поховальної кераміки. За формою до березанських посудин ближче за все посуд варіанту Д цього некрополю18. Про генетичний зв'язок банкоподібного посуду із матеріалів архаїчних античних пам'яток $з$ посудом Карпато-Дунайського басейну писав К.К. Марченко ${ }^{19}$. Але В.В. Лапін, досліджуючи банкоподібні посудини, наводив зразки ліпних банкоподібних посудин з Олінфуㄹ. Підкреслимо лише те, що ліпний посуд «фракійського» вигляду, котрий має аналогії як в архаїчних античних пам'ятках Греції, так і в архаїчних пам'ятках Карпато-Дунайського басейну, з'являється на поселенні на о. Березань разом з першими грецькими колоністами. На території острова та прилеглих до нього регіонів стаціонарні поселення періоду бронзи не зафіксовані. Декілька банкоподібних посудин із «кіммерійських» поховань регіону відрізняються від наведених вище і розмірами, і формою, і формовочною масою21. Можливо певну ясність у питанні появи цього посуду внесе його дослідження за допомогою методів природничих наук.

Нехарактерним для ліпного посуду періоду ранньої архаїки є лише один фрагмент горщика з горлом у вигляді розтрубу, орнаментований пальцево-нігтьовими відбитками (АБ75-10), що походить з напівземлянки 58 (рис. 3, 1). Найближчою аналогією цій посудині є знахідка з ями 120 з розкопок «0-Західного» ${ }^{22}$. Денце лощеної посудини з господарської ями 176 могло належати горщику середніх розмірів (АБ75-359, рис. 3, 2). Групу закритого посуду завершує вінчик лощеної товстостінної корчаги з господарської ями 176 (АБ75-358, рис. 3, 3).

Відкритий посуд представлений трьома посудинами. Невелика товстостінна чашка напівсферичної форми із загорнутим до середини вінцем, орнаментованим глибокими косими нарізками на зрізі, походить з напівземлянки 71 (АБ77-326, рис. 3,4$)$. Найближча аналогія походить з матеріалів інших ділянок поселення 23. У найнижчому прошарку напівземлянки 58 знайдена частина миски із м'яким бортиком і ледь скошеним до середини краєм. Діаметр посудини 18 см (АБ75-12, рис. 3,6 ). 3 напівземлянки 71 походить миска у формі зрізаного конусу із загорнутим краєм (АБ77-354, рис. 3, 5). Найближчі аналогії з матеріалів 2007 р. ${ }^{24}$

\section{Друга половина VII - початок VI ст. до н.е. «після стихійного лиха».}

Матеріалом для опису керамічного посуду зазначеного періоду стали знахідки 3 трьох напівземлянок округлої (65), дві (59; 65а) прямокутної із заокругленими кутами форм і п'ять $(1 ; 52 ; 162 ; 169 ; 172)$ господарських ям (табл. 1). Зауважу, що контури напівземлянок 65 і 65а майже співпали. Ці споруди розділено на основі стратиграфії та кількісно-якісних оцінок матеріалів. Напівземлянка 65а за часом скоріше за все відноситься до першої половини VI ст. до н.е. Однак описується вона тут, оскільки зафіксовано випадок прямої стратиграфії. Асортимент кераміки та їх відсоток представлений у табл. 3.

\footnotetext{
18 Vulpe Al. Nekropola Hallstattzeıt de la Ferıgıle. Bucureștı, 1967. fig. 16, 10.

19 Марченко К.К. Фракийцы на территории Нижнего Побужья во второй половине VII-I вв. до н.э. // Вестник древней истории. 1974. № 2. С. 146-162.

20 Лапин В.В. Греческая колонизация Северного Причерноморья... С. 163-164.

${ }^{21}$ Гаврилюк Н.А. Лепная керамика ранних кочевников Северного Причерноморья (IX - первая половина VII вв. до н.э.). Киев, 2017. С. 144-146.

22 Чистов Д.Е., Зуев В.Ю., Ильина Ю.И., Каспаров А.К., Новоселова Н.Ю. Материалы Березанской (Нижнебугской) античной археологической экспедиции... С. 37, 38, 202, табл. 46, 5.

23 Ibid. C. 37, 38, 203, табл. 47, 4

24 Ibid. C. 37, 38, 203, табл. 46, 3; 46, 1, 6.
} 
Для об’єктів другого періоду «частка вивченості» керамічного матеріалу (співвідношення знахідок, занесених до польових списків і знахідок кераміки включених до вивчення) коливається у межах від 19 до 30\%. Це суттєво відрізняє напівземлянки періоду «до стихійного лиха» і періоду кінця VII - початку VI ст. до н.е. «після стихійного лиха». Ці порівняння правомірні, оскільки йдеться про споруди одного типу на одному поселенні, розташовані в одному його районі та досліджені за однією методикою.

У матеріалах напівземлянок обох періодів розписний парадний посуд переважає. Але у напівземлянках «до стихійного лиха» його кількість становить від 52 до $74 \%$ (рис. 4) (середній показник 60\%), а у спорудах другої половини VII - початку VI ст. до н.е. кількість розписного посуду коливається у межах від 56 до 76\%, а середній показник - 63\% (табл. 3). Тобто, кількість імпорту посуду зростає. Змінюються й якісні показники, про що йтиметься нижче.

Табл. З. Керамічний комплекс напівземлянок та господарських ям (друга половина VII - початок VI cm. до н.е.)

\begin{tabular}{|c|c|c|c|c|c|c|c|c|c|c|}
\hline \multirow[b]{3}{*}{$\begin{array}{r}\text { Групи кера- } \\
\text { міки }\end{array}$} & \multicolumn{10}{|c|}{ Номери об’єктів } \\
\hline & \multicolumn{4}{|c|}{ Напівземлянки (НПЗ) } & \multicolumn{6}{|c|}{ Господарські ями (ГЯ) } \\
\hline & $\begin{array}{l}59 \\
(\%)\end{array}$ & $\begin{array}{c}65 \\
(\%)\end{array}$ & $\begin{array}{l}65 a \\
(\%)\end{array}$ & $\begin{array}{c}\text { середнє } \\
(\%)\end{array}$ & $\begin{array}{c}1 \\
(\%)\end{array}$ & $\begin{array}{c}52 \\
(\%)\end{array}$ & $\begin{array}{l}162 \\
(\%)\end{array}$ & $\begin{array}{l}169 \\
(\%)\end{array}$ & $\begin{array}{l}172 \\
(\%)\end{array}$ & $\begin{array}{c}\text { середнє } \\
(\%)\end{array}$ \\
\hline Розписна & 55,5 & 75,9 & 58,52 & 63,3 & 61,33 & 36,92 & 36,67 & 73,47 & 69,57 & 58,5 \\
\hline Ліпна & 16,41 & 9,11 & 13,65 & 13,1 & 11,41 & 12,32 & 48,33 & 20,41 & 21,74 & 19,96 \\
\hline Червоноглин & 4,88 & 5,91 & 5,57 & 5,5 & 7,41 & 18,46 & 1,67 & 0 & 0 & 5,5 \\
\hline Сіроглиняна & 7,81 & 4,93 & 10,13 & 7,6 & 5,92 & 24,61 & 10,0 & 6,12 & 6,52 & 9,4 \\
\hline Кухонна & 8,20 & 0,99 & 8,75 & 6 & 11,26 & 0 & 3,33 & 0 & 0 & 3,4 \\
\hline Товстостінна & 0 & 0,49 & 1,89 & 0,7 & 0 & 0 & 0 & 0 & 2,17 & 0,37 \\
\hline Піфоси & 0 & 1,72 & 1,35 & 1 & 0 & 0 & 0 & 0 & 0 & $\mathbf{0}$ \\
\hline Чорнолакова & 7,23 & 0,99 & 0,14 & 2,8 & 2,67 & 7,69 & 0 & 0 & 0 & 2,6 \\
\hline & 100 & 100 & 100 & 100 & 100 & 100 & 100 & 100 & 100 & 100 \\
\hline
\end{tabular}

Друге місце за кількістю знахідок, як і в першому періоді, займають фрагменти ліпного посуду - від 9 до 16\% (рис. 4), середній показник - близько 14\%, а у спорудах другого періоду - у напівземлянках - середній показник 13\%, а напівземлянках - 19\% (табл. 3). Тобто, виникає тенденція до зменшення кількості ліпного посуду, але збільшується кількість гончарного кухонного - з 2,9\% у першому періоді й 6\% у середньому - у другому періоді (табл. 2 і 3). Зменшується кількість і товстостінного господарського посуду. Його частка коливається від 0,5\% до 2\%, середній показник - 0,7 (у перший період - від 0,14 до 1,74\%, середній - 1,2\%, табл. 2). Піфоси у другий період зафіксовані лише у двох напівземлянках (табл. 3).

Трохи більше, ніж у попередній період починає використовуватися сіроглиняний столовий посуд. Його асортимент залишається майже незмінним (ойнохої, глечики, миски), частка коливається від 4,93 до 10,13\%, середній показник - 7,6\% (табл. 3) (у попередній період - від 3,84 до 9,45\%, середній - 6\%, табл. 2).

А от кількість червоноглиняного столового посуду трохи зменшується. У другий період його показники коливаються у межах 4,88-5,91\%, середній показник 5,5\% (табл. 3), а у перший період - середній показник 10\% (табл. 2).

До групи об'єктів другої половини VII - початку VI ст. до н.е. відносяться п’ять господарських ям, коротка характеристика яких надана у табл. 1. У порівнянні із 
заповненням синхронних напівземлянок керамічні групи з господарських ям не зазнали суттєвих змін, а кількісні показники помітно різняться (табл. 3). Розписний посуд, як і в напівземлянках, займає чільне місце, але середній показник його присутності у господарських ямах менший і складає 58,5\%. Показник ліпного посуду з господарських ям значно більший - 19,96 на відміну від 13,1\% у напівземлянках, а кількість гончарного кухонного в ямах зменшується - 3,4\% на відміну від 6\%. Дані по червоноглиняному та чорнолаковому посуду з господарських ям майже співпадають з даними з напівземлянок (рис. 4; 5).

Отже, основний набір побутового посуду перших мешканців поселення на о. Березань складався з розписного посуду, ліпного, сіроглиняного та червоноглиняного, і товстостінного посуду. Розписний посуд переважав упродовж всього відрізку часу: у напівземлянках «до стихійного лиха» він складав близько 60\%, а «після стихійного лиха» - 63,3\% побутового керамічного набору.

У другий період його кількість дещо збільшилася. Напівземлянку 59 датують раннім періодом такі знахідки: чаші птахом (3.76) - 625/600-590 рр.; столової гідри з хвилястим декором (1.300) - 625-600 рр. до н.е.; стінка посудини (1.29) стилю MiLA Id/SıA Ic - рання SiA Id - 630-610/600 рр. Тобто, більшість розписного посуду з напівземлянки відноситься до останньої чверті VII ст. до н.е. Пізнішим часом датується тільки ольпоподібний аск (6.151) - 610-590 pp. 25

Землянка 65, згідно з даними аналізу розписної кераміки, відноситься (ранні прошарки) до кінця VII - початку VI ст. до н.е. Таке датування (610-590 рр.) базується на знахідці фрагмента тарілки, прикрашеної квітами лотоса (1.275). Знахідки фрагментів коринфських посудин (11.32 і 11.78) свідчать про існування садиби і на початку VI ст. до н.е. - 590-570 та близько 570 р до н.е. ${ }^{26}$

Винятково у межах VI ст. до н.е. датується напівземлянка 65а. Про це свідчать знахідки хіосських кубка і чорнофігурної тарілки (8.9; 8.104), кришка діноса (2.82) стилю LWG/NıA I; дверцят латерни (6.69), стінка пізньокоринфського (11.163 ПК 1) кратера та глечик (6.35) місцевого виробництва прикрашений хвилястою лінією27.

Найбільш ранньою є господарська яма 172, в якій знайдено фрагмент чаші (3.84) типу IV (з птахами), котра відноситься до 625-600 pр. до н.е. 3 цієї ж ями походять фрагменти двох південно-іонійських ойнохой типів MıLA Id/paнній SiA Ic та MıA Ie/SıA Id , що датуються відповідно 620 р. та 615/610-590/580 pр. до н.е.28 Єдиною датуючою знахідкою для господарської ями $169 є$ фрагмент чаші (3.1), орнаментованої у стилі LWG/NıA I, що вказує на дату 590/580-570 рр. ${ }^{29}$ Рідкісний етруський канфар (12.1) з господарської 62 датується останньою чвертю VII - першою чвертю VI ст. до н.е. ${ }^{30}$ Підставою для датування 600/599-575 рр. до н.е ями $1 \epsilon$ чаша 3.101 (з магічними очами) ${ }^{31}$. У господарській ямі 52 знайдено столові південно-іонійські амфори: 1.308 кінця VII - початку VI ст. до н.е. і більш пізня 1.149 -

\footnotetext{
25 Буйских А.В. Архаическая расписная керамика... С. 92, 284, рис. 76; С. 39, 239, рис. 31; С. 14, 210, рис. 2; С. 142, 337, рис. 129.

26 Ibid. С. 35, 236, рис. 28; С. 174, 365, рис. 157; С. 178, 371, рис. 163.

27 Ibid. С. 160 , 356, рис. 148 ; С. 151,343 , рис. 135 ; С. 71 , 263, рис. 55 ; АБ 19, С. 135,328 , рис. 120 ;

С. 185,381 , рис. $173 ;$ С. 133,325 , рис. 117.

28 Ibid. С. 92,284 , рис. 76 ; С. 14,210 , рис. 2; С. 15,211 , рис. 3.

29 Ibid. С. 86, 278, pис. 70.

30 Ibid. С. 190-191, 388, рис. 180.

31 Ibid. C. 94, pис. 77.
} 
560-550 рр. до н.е. Північно-іонійська амфора групи Борисфена (2.155) відноситься до $580-560$ рр. до н.е. 32

Весь ліпний посуд, котрий займає друге місце за кількістю у побутовому керамічному наборі мешканців поселення на о. Березань (середній показник для споруд другої половини VII - початку VI ст. до н.е. - 19,96\%), виготовлений з одноманітної формувальної маси з грубими домішками, ідентичної до формувальної маси ліпної кераміки першого періоду. Ця технологічна група переважає у другому періоді, але у цей час вона не є єдиною.

У колекції ліпного посуду з напівземлянок другої половини VII - початку VI ст. до н.е. переважають банкоподібні посудини з наміченою шийкою (орнамент - масивний наліпний валик із защипами (рис. 6, 1), косими пальцево-нігтьовими насічками (рис. 6, 2, 3), або пальцевими вдавленнями (рис. 6, 6). Вперше з'являються пальцеві защипи на зовнішньому зрізі вінець (рис. 6, 4, господарська яма 162-1974) й овальні виступи-ручки, котрі переривають валик, розташований на шийці посудини (рис. 6, 5, напівземлянка 65-1976).

Банкоподібні посудини з прямим або трохи скошеним до середини горлом складають чи не половину всіх посудин ліпного керамічного посуду другої половини VII - початку VI ст. до н.е. (рис. 6, 7-12). В орнаментації таких посудин переважає відтягнутий валик з неглибокими пальцево-нігтьовими відбитками (рис. 6, 7, $8,11,12)$, або з насічками (рис. 6,10$)$. Для посудин описаних типів характерні проколи під вінцями, наприклад (рис. 6,12 - для підвішування?) або на стінках (ремонт?).

Горщики з дугоподібною у розрізі шийкою представлені знахідками з напівземлянок (П3 65a) і з господарських ям (52-64; 162-74) (рис. 7, 1-3). Як правило, такі горщики орнаментувалися пальцевими відбитками на вінцях (рис. 7, 3). Унікальним можна вважати тонкостінний горщик невеликих розмірів з високим дугоподібним горлом, прикрашеним відтягнутим знизу валиком з пальцевими відбитками (рис. 7,2$)$. Зовнішня поверхня посудини яскравого оранжевого кольору, 3 тріщинами.

Горщики з горлом у вигляді розтрубу представлені знахідками з господарської ями 169 (рис. 7, 4-6). Вінця таких горщиків були прикрашені косими насічками на зрізі (рис. 7, 4) або нігтьовими насічками по зовнішньому краю (рис. 7, 5). Невеликий горщик мав коротке горло, верхня частина якого підкреслена невеликим потовщенням на зовнішній поверхні. Це посудина із слідами ремонту - два отвори на одній стороні вертикальної тріщини (рис. 7, 6).

Група відкритого посуду представлена мисками різних типів: переважали напівсферичні товстостінні посудини (рис. 8, 1, 2, 4). До цього ж типу відноситься і невелика посудинка напівсферичної форми - чашка (рис. 8, 2). Унікальною є лощена товстостінна миска з вертикальним краєм і горизонтальним ребром, підкресленим низкою з косих коротких рівчачків і підпрямокутним виступом-ручкою (рис.8,3). Ця посудина відноситься до лощених мисок культури БасарабьШолданєшть, котрі іноді зустрічаються на пам'ятках передскіфського періодуз3. У значній кількості миски з жолобками чи каннелюрами зустрічаються на пам'ятках ранньоскіфського лісостепу, де синхронізуються з розписним посудом, аналогіч-

\footnotetext{
32 Ibid. С. 40, 240, рис. 32; С. 25; С. 57, 253, рис. 45.

33 Гаврилюк Н.А. Лепная керамика ранних кочевников... С. 138, 294-295.
} 
ним знайденому на Березані та датуються періодом Немирів III.1.3, тобто, другою половиною VII - першою третиною VI ст. до н.е. ${ }^{34}$ Подібній мисці, але з лощеними зовнішньою та внутрішньою поверхнями, належить дно посудини з напівземлянки 59-75 (рис. 8, 6). Аналогії конусоподібній мисці з прямим вінцем, виділеним горизонтальним ребром-виступом (рис. 8, 5) поки що невідомі.

Досить звичайними знахідками у шарах першої половини VI ст. до н.е. з поселення є відкриті світильники з виступом у центрі. Фрагмент такого світильника знайдено у господарській ямі 52-1964 (рис. 8, 7).

Досить часто у культурних шарах поселення зустрічаються ліпні диски. Найранішим є диск з напівземлянки 59-1964 (рис. 8, 9).

Першою половиною VI ст. до н.е. може бути датований кубок з прямим горлом, кулеподібним тулубом і пласким дном з напівземлянки 65а. Він орнаментований прокресленим орнаментом у вигляді вертикальних паралельних відрізків, що спускаються на тулуб посудини від двох рядів наколів, розташованих в основі шийки посудини. Одна з таких парних ліній додатково прикрашена невеликими заштрихованими трикутниками з «прапорцем» (рис. 8, 8). Майже точною за розмірами та формою аналогією кубку з напівземлянки 65а є кубок з могильника на о. Березань, розкопаного Г.Л. Скадовським у 1900-1901 р., що зберігається у фондах Херсонського обласного краєзнавчого музею (шифр А-5360 КП 17924).

Порівнюючи ліпний посуд з об'єктів «до стихійного лиха» і «після стихійного лиха», відзначимо, що кількість посуду першого періоду менша за кількість другого періоду та дуже одноманітна - переважають банкоподібні посудини з однотиповою орнаментацією. Відносно ліпного посуду другого періоду - його кількість збільшується у господарських ямах та урізноманітнюється його асортимент. Можна сказати, що саме у другій половині VII - на початку VI ст. до н.е. починає формуватися набір побутового ліпного посуду.

Змінюється співвідношення гончарної кухонної кераміки та ліпної. Якщо ліпний посуд «до стихійного лиха» був чи не основним видом кухонного начиння співвідношення ліпного та гончарного «до стихійного лиха» 16:2,9 (майже у 6 разів більше); «після стихійного лиха» 13:6 (всього у 2 рази більше).

\section{Обговорення матеріалу.}

Отже, перші колоністи висадились на о. Березань з амфорами та розписним посудом, призначеним в основному на обмін, і певним набором побутового посуду. До цього набору входили (крім амфор і розписного посуду на обмін, якась частка, яку ми не можемо визначити, для власного використання) ліпний посуд, гончарний кухонний, господарський товстостінний. У невеликій кількості - червоноглиняний і сіроглиняний посуд. Ці тенденції простежуються, у першу чергу, за матеріалами напівземлянок.

У наступний відрізок часу, після стихійного лиха, набір побутового посуду змінюється - зростає у кількісному та якісному відношенні відсоток розписного посуду, збільшується кількість сіроглиняної та сіролощеної кераміки, але зменшується відсоток червоноглиняної. Це прослідковується на матеріалах як напівземлянок, так і господарських ям.

\footnotetext{
34 Смирнова Г.И., Вахтина М.Ю., Кашуба М.Т., Старкова Е.Г. Городище Немиров на реке Южный Буг. Санкт-Петербург, 2018. С. 173, рис. 144; С. 229, рис. 169, С. 235.
} 
Важко пояснити велику частку ліпної кераміки у складі побутового начиння перших переселенців присутністю варварського населення (не чекали їх на острові варвари лісостепу, оселі яких знаходилися у городищах, розташованих у 500600 км від узбережжя і тим більше - від острова). До того ж більше, у складі ліпного керамічного комплексу перших періодів існування поселення власне «лісостепова» кераміки відсутня. Вона з'являється у Побужжі десь з середини VI ст. до н.е. Ще менш вірогідними $є$ перші контактами з кочовими скіфами. Степова зона Північного Причорномор'я у цей період слабо заселена та й навряд чи кочовики, які не люблять «великої води», чекали на острові мореплавців.

Складається враження, що В.В. Лапін був правий щодо інтерпретації феномену ліпного посуду у матеріалах античних пам'яток Північного Причорномор'я і що ліпна кераміка з'являється у Борисфені разом з прибульцями. Якщо ми визнаємо це, залишається три варіанти способів її тут появи:

- $\quad$ у складі майна, яке брали з собою мореплавці з міста-метрополії. Таке можна припустити для деяких видів розписного посуду, або гончарного кухонного (наприклад, гончарні хітри (горщики з ручкою, що мають аналогії у кераміці Мілету). Однак велика кількість ліпного посуду у перших напівземлянках не дозволяє прийняти це припущення.

- $\quad$ у складі керамічного «товару», який могли отримати переселенці у випадку «каботажного плавання» уздовж західного узбережжя Чорного моря й обмінних відносин з місцевими племенами. На користь цієї версії свідчить однорідність ліпного керамічного посуду та переважання аналогій серед кераміки «фракійського» вигляду.

- $\quad$ наліпити ліпні банкоподібні горщики могли перші переселенці. Певні навики цього нескладного процесу вони пам'ятали, сировина у вигляді місцевих глин була. 3 огляду на те, що вже у середині VI ст. до н.е. на острові вже існували гончарні печі для виготовлення «іонійського» посуду 35 , то раніше зліпити горщик, який би задовольнив перші «кухонні» потреби для перших мешканців поселення на о. Березань, не складало б великих труднощів.

\section{Висновки.}

1. Підтвердилось припущення В.В. Лапіна про те, що перші грецькі мореплавці з'явились на о. Березань ще «до стихійного лиха», приблизно на початку останньої чверті VII ст. до н.е. Набір їх побутового посуду небагатий: в основному розписний посуд, більшість якого йшла на обмін, і ліпний для побуту.

2. Показані перспективи використання статистичних методів у вивченні кераміки. Саме вони дозволяють використовувати весь масовий археологічний матеріал і провести більш точну його оцінку. Більш того, вивчення співвідношень груп побутового посуду може дати додаткові аргументи у процес датування археологічних об'єктів.

3. Набір і кількість посуду другого періоду, кінця VII - початку VI ст. до н.е. стає більш різноманітним і збільшується у кількості. Починає формуватися асортимент кераміки кожної групи, який у наступні періоди стає визначальним у матеріальній культурі Борисфену. Але дослідженню цих процесів будуть присвячені подальші роботи.

35 Крутілов В.В. Керамічні печі з Борисфена середини VI ст. до н.е. // Археологія. 2015. № 2. С. 116124. 
4. Аналіз масового керамічного матеріалу з розкопу «Основний» дозволяє приєднатися до гіпотези В.В. Лапіна про появу ліпного посуду у перших грецьких колоністів завдяки заселенню найпівнічнішого регіону ойкумени.

5. Продовження досліджень масового керамічного матеріалу у широких хронологічних та територіальних межах дозволить змінить деякі наші уявлення про матеріальну культуру Північного Причорномор'я античного часу.

\section{REFERENCES}

Buiskikh, A.V. (2019). Arkhaicheskaia raspisnaia keramika iz Borisfena [Archaic painted ceramics from Borisphen]. Kiev [in Russian]

Chistov, D.E. (2017). Severo-vostochnyi raion Berezanskogo poseleniia [North-Eastern district of the Berezan Settlement]. In Peripl ot Borisfena do Bospora. Materialy yubileinykh konferentsiy. Gosudarstvennyi Ermitazh, (p. 7-31). Sankt-Petersburg [in Russian].

Chistov, D.E., Zuev, V.Yu., Ilyina, Yu.I., Kasparov, A.K. \& Novoselova, N.Yu. (2012). Materialy Berezanskoi Nizhnebugskoi antichnoi arkheologicheskoi ekspeditsii Issledovanie na o. Berezan v 2005-2009 gg. [Materials of the Berezan Nizhnebug antique archaeological expedition. Research on Berezan in 2005-2009]. Vol. 2. Sankt-Petersburg [in Russian].

Chistov, D.E., Ilyina, Yu.I. \& Shcherbakova, O.E. (2015). Kukhonnoe oborudovanie i kukhonnaia keramika arkhaicheskogo Berezanskogo poseleniia [Kitchen equipment and kitchen ceramics of the archaic Berezan settlement]. Klio, 11 (107), 13-26 [in Russian].

Gavrylyuk, N. (2018). Greeks and Barbarians of the Northern Back Sea area during the Archaic period (the end of the $7^{\text {th }}-6^{\text {th }}$ centuries $\mathrm{BC}$ ). In Actuale archeologique ukrainienne: Olbia pontique, lelime et les Barbares. Lausanne, 12-18.

Gavrylyuk, N.A. (2017). Lepnaia keramika rannikh kochevnikov Severnogo Prichernomoria (IX - pervaia polovina VII vv. do n.e.) [Stucco pottery of the early nomads of the Northern Black Sea region (IX first half of the VII centuries BC)]. Kiev [in Russian].

Krutilov, V.V. (2015). Keramichni pechi z Borisfena seredyny VI st. do n. e. [Ceramic kilns from Borisfen in the middle of the $6^{\text {th }}$ century BC]. Arkheolohiia, 2, 116-124 [in Ukrainian].

Lapin, V.V. (1966). Grecheskaia kolonizatsiia Severnogo Prichernomoria [Greek colonization of the Northern Black Sea region]. Kiev [in Russian].

Lapin, V.V. (1975). Otchet o raskopkakh drevnegrecheskogo poselenia na o. Berezan v 1975 godu [Report on the excavation of an Ancient Greek Settlement on the Island Berezan in 1975]. The Scientific Archive of Institute Archaeology NAS of Ukraine, 1975/114 [in Russian].

Lapin, V.V. (1976). Otchet o raskopkakh drevneurecheskogo poselenia na o. Berezan v 1976 godu [Report on the excavation of an Ancient Greek Settlement on the Island Berezan in 1976]. The Scientific Archive of Institute Archaeology NAS of Ukraine, 1976/116 [in Russian].

Lapin, V.V. (1977). Otchet o raskopkakh drevneurecheskogo poselenia na o. Berezan v 1977 godu [Report on the excavation of an Ancient Greek Settlement on the Island Berezan in 1977]. The Scientific Archive of Institute Archaeology NAS of Ukraine, 1977/98 [in Russian].

Lapin, V.V. (1978). Berezan i problem genezisa antichnoy severo-prichernomorskoy tsivilizatsii [Berezan and the problems of the genesis of the ancient civilization in the North Black Sea Region]. The Scientific Archive of Institute Archaeology NAS of Ukraine, 24 [in Russian].

Marchenko, K.K. (Ed.) (2005). Greki i varvary Severnogo Prichernomoria v skifskuiu epokhu [Greeks and barbarians of the Northern Black Sea Region in the Scythian Era]. Sankt-Petersburg [in Russian].

Marchenko, K.K. (1974). Frakiytsy na territorii Nizhnego Pobuzhia vo vtoroi polovine VII - I vv. do n.e. [Thracians on the territory of the Lower Bug Region in the second half of the VI - I centuries BC]. Vestnik drevnei istorii, 2, 146-162 [in Russian].

Marchenko, K.K. (1986). Lepnaja keramika [Stucco pottery]. In Kultura naseleniia Olvii i eio okrugi $v$ arkhaicheskoe vremia, Kiev, 104-115 [in Russian].

Senatorov, S.N. (2005). Lepnaia keramika poseleniia na ostrove Berezan iz raskopok Gosudarstvennogo Ermitazha 1963-1991 gg. [Stucco pottery of the settlement on the Berezan Island from the excavations of the State Hermitage in 1963-1991]. In Borisfen-Berezan. Arkheologicheskaia kollektsiia Ermitazha, (Vol. 1, pp. 174-350) Sankt-Petersburg [in Russian].

Smirnova, G.I., Vakhtina, M.Yu., Kashuba, M.T. \& Starkova, E.G. (2018). Gorodishche Nemirov na reke Iuzhni Bug [The settlement of Nemyriv on the Southern Bug River]. Sankt-Petersburg [in Russian].

Vakhtina, M.Yu. (2018). Grecheskaia keramika iz raskopok Nemirovskogo gorodishcha [Greek ceramics 
from the excavations of the Nemirov Settlement]. In Smirnova, G.I., Vakhtina, M.Yu., Kashuba, M.T. \& Starkova, E.G. Gorodishche Nemirov na reke Yuzhnyi Bug, (pp. 193-223). Sankt-Petersburg [in Russian].

Vulpe, Al. (1967). Nekropola Hallstattzeit de la Ferıgıle. Bucureștı.

Zadnikov, S.A. (2017). Torgovye otnosheniia Belskogo gorodishcha s Berezaniu [Trade relations the settlement Belsky with Berezan]. In: Peripl ot Borisfena do Bospora. Materialy iubileinykh konferentsii Gosudarstvennyi Ermitazh (pp. 65-74). Sankt-Petersburg [in Russian].

\section{Nadiya Gavrylyuk}

(Institute of Archaeology National Academy of Sciences of Ukraine, Kyiv, Ukraine)

e-mail: gavrylyuk_na@ukr.net

ORCID: https://orcid.org/0000-0002-2369-5701

\section{Borysthenes Ceramic Complex of Early Archaic Period (on Collection of V.V. Lapin Materials)}

The problem under consideration is the ethnicity of the population that used or created handmade pottery for the first inhabitants of ancient Borysthenes. A ceramic complex of the settlement on the island Berezan, like other settlements of the Northern Black Sea coast of ancient times, is considered being one of the ethnic indicators of its inhabitants.

V.V. Lapin considered the handmade ware to be an organic element of Greek material culture and disputed the hypothesis that the handmade pottery from the cultural layers of ancient settlements belonged to the Scythians. The opposite view is held by scholars, who though no longer consider handmade pottery to be Scythian, but associate it with a barbarian element in the population of ancient centers. This relevant issue can be resolved through the study of pottery from the settlements of the early archaic.

The goal of the study is to define the collection of pottery of the second half of the $7^{\text {th }}-$ early $6^{\text {th }}$ century BCE, to find the ratio of the main groups of pottery in the household of the first inhabitants of the settlement, and to determine the typology of handmade pottery of the first archaic period, taking into account the recently proposed dating of painted pottery.

The methods of ceramic material study are changed with the involvement of mass material and showing its changes in a wide chronological range. The entire household (without amphorae container) ceramic complex of the settlement is shown.

The assumption of V.V. Lapin that the first Greek sailors appeared on Berezan just 'before the disaster', approximately at the beginning of the last quarter of the $7^{\text {th }}$ century BCE, is confirmed. Their kitchen utensils included (except for amphorae) handmade, kitchen, and household thickwalled pottery. In small quantities, there were earthenware and stoneware clay vessels.

Diversity and quantity of utensils increase during the second period, late $7^{\text {th }}-$ early $6^{\text {th }}$ century BCE. The assortment of items of each group begins to form, which in the following periods becomes decisive in the material culture of Borysthenes.

Analysis of mass ceramic material from the excavation 'Osnovnyi' (Main) allows us to support the statement of V.V. Lapin about the appearance of handmade pottery in the first Greek colonies owing to the settlement of the northernmost region of Ecumene.

Continuing the study of mass ceramic material in wide chronological and territorial boundaries will change some of our ideas about the material culture of the Northern Black Sea coast at ancient times.

Keywords: Berezan, Borysthenes, handmade pottery, dating, Greeks, barbarians 


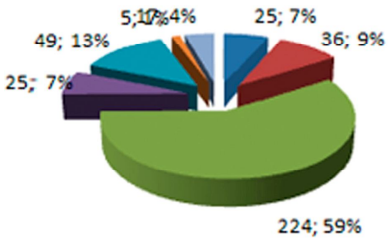

НП3 58-75 ш Червоноглиняна

= Сіролощена $\mathrm{i}$
чорнолощена
= Розписна
घ Кухонна
= Ліпна
= Товстостінна

๓ Чорнолакова

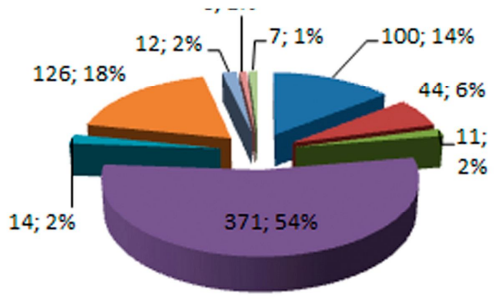

НП3 71-77
— Сіроглиняна

믈 Коринфська

문йська

— Кухонна

п Ліпна

ㅁ. Товстостінна

푸 Червонолакова

Світильник

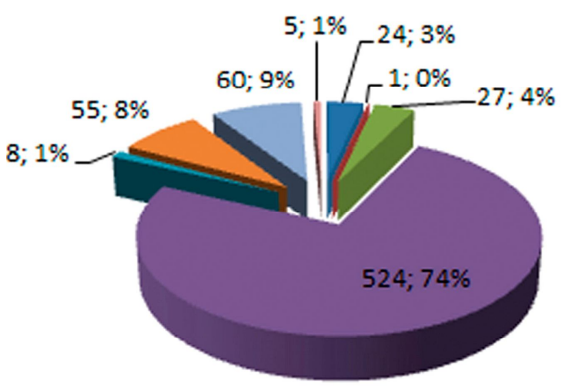

нПз 70-77

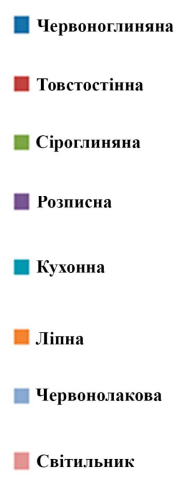

— Світильник оноглиняна Фіроглиняна пухонна —ліпна

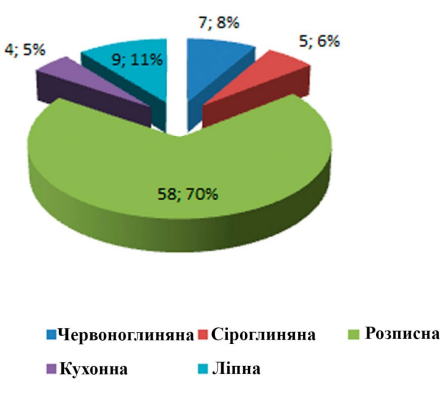

гя 176- 75

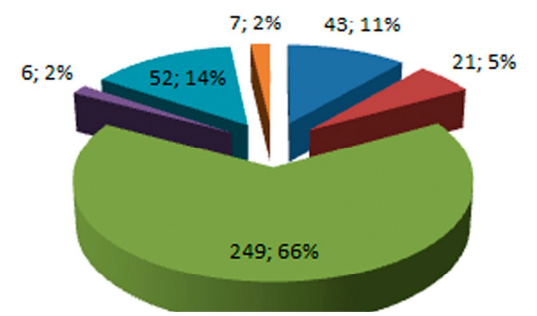

НП3 $72-77$

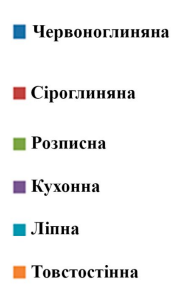

п Товстостінна

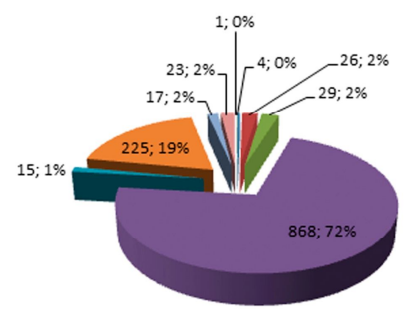

гя 6/н-75

Рис. 1. Діаграми заповнення керамікою напівземлянок (НПЗ) та господарських ям (ГЯ) (до стихійного лиха). 


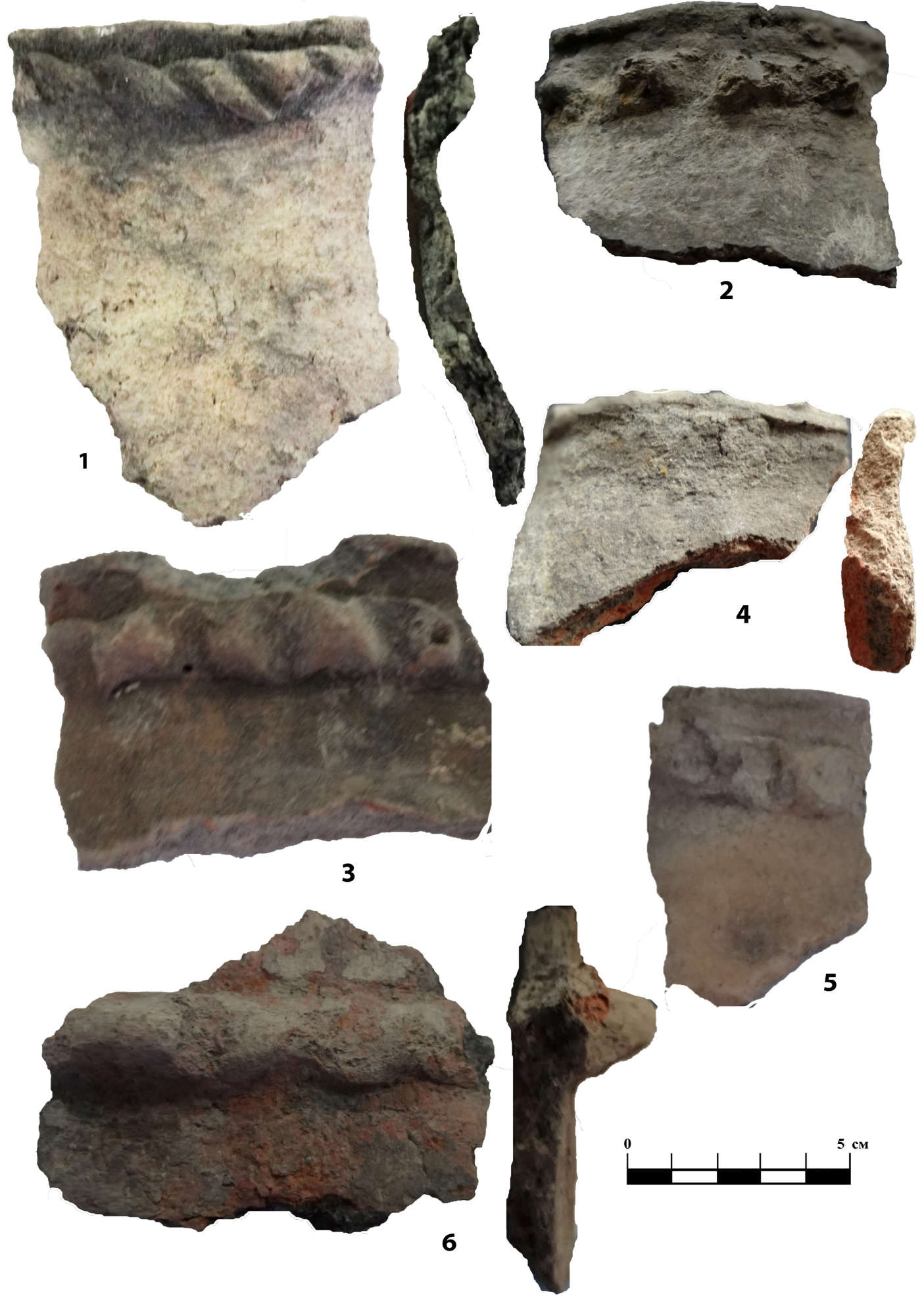

Рис. 2. Банкоподібний посуд зі споруд, що виникли «до стихійного лиха»: посудини 3 наміченою шийкою (1-3); посудина з ледь наміченою шийкою (4); посудина з прямим горлом (5); велика посудина (із скошеним до середини вінцем?) (5). 

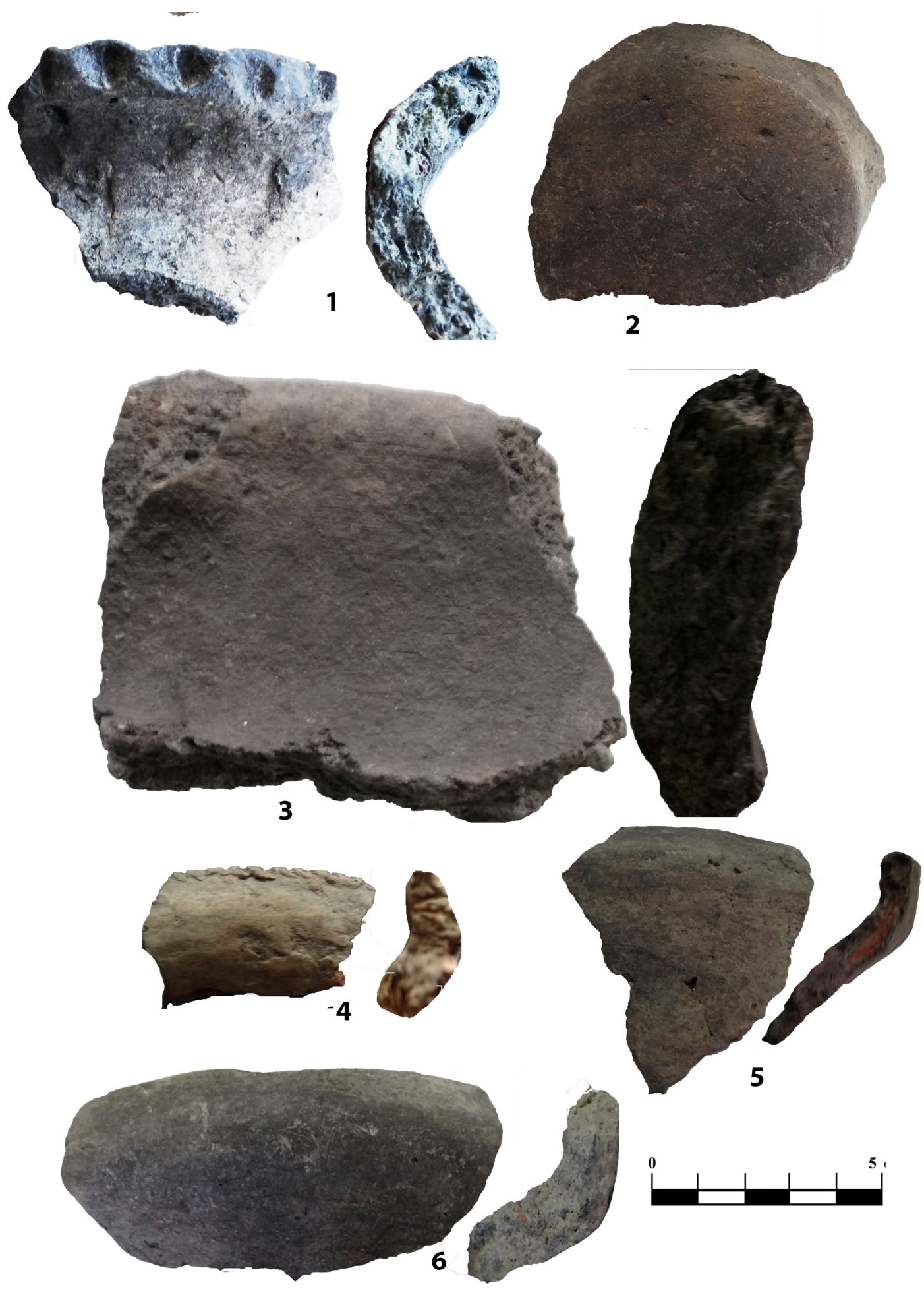

Рис. 3. Закритий та відкритий ліпний посуд зі споруд, що виникли«до стихійного лиха»: 1-горщик з горлом у вигляді розтрубу;2 - денце лощеного горщика; 3 - корчага; 4 - чашка з орнаментом; 5 - миска конусоподібної форми; 6 - миска з загорнути венцем. 


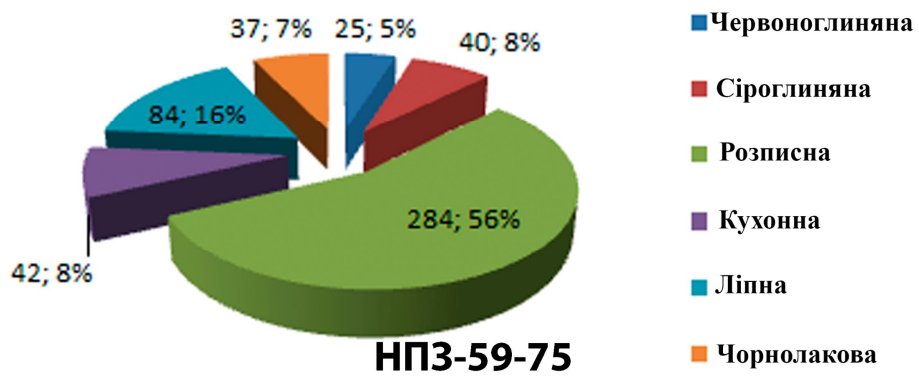

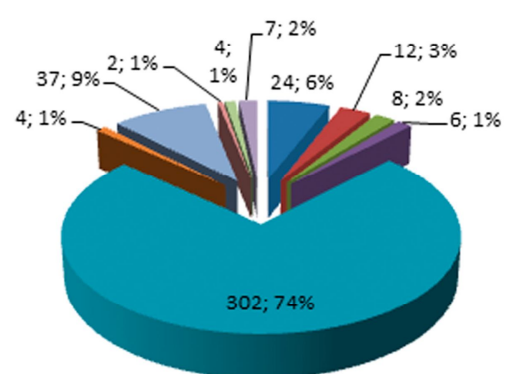

НП3-65-76

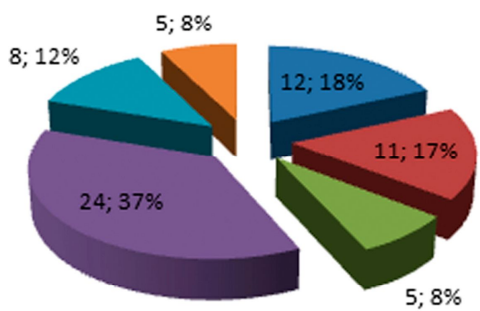

Гя 52-64

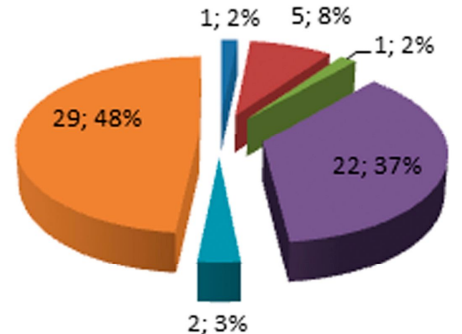

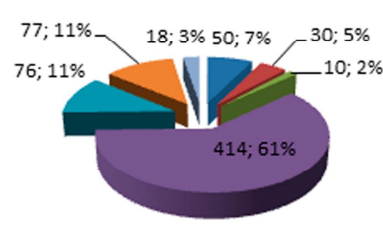

гя 1-60
․ Червоноглиняна

․ㅡ Сіроглиняна

п Сіролощена

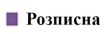

匹 Кухонна

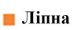

- Червонолакова

ліпна

들 Товстостінна

"ᄑ Червонолакова

프 Пiфос

- Червоноглиняна

п Сіроглиняна

둥лощена i чорнолощена

— Іонійська

— Ліпна

червонолакова

п Сіроглиняна

— Сіролощена i чорнолощена

— Іонійська

пухонна

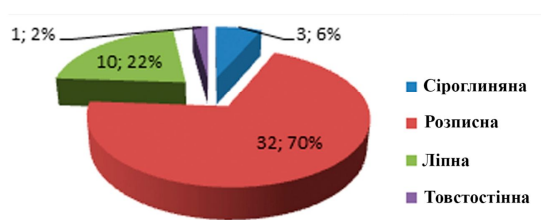

Гя 172-75

ГЯ 162-74 ๒ Ліпна

Рис. 4. Діаграми заповнення керамікою напівземлянок (НПЗ) та господарських ям (ГЯ) (друга половина VII - початок VI ст. до н.е.). 


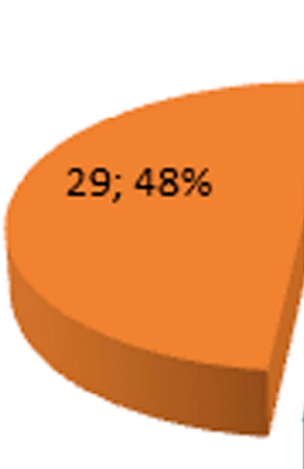

$1 ; 2 \% \quad 5 ; 8 \%$

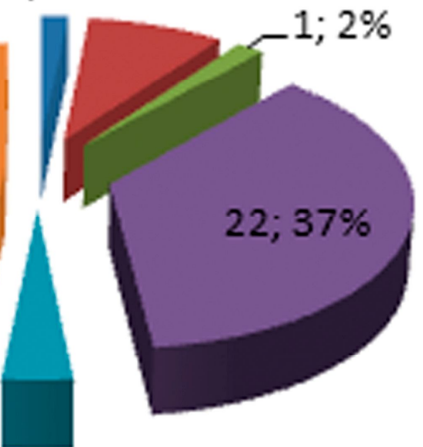

$2 ; 3 \%$

Гя 162-74

Сіроглиняна

Сіролощена i

чорнолощена

Іонійська

Кухонна

- Ліпна

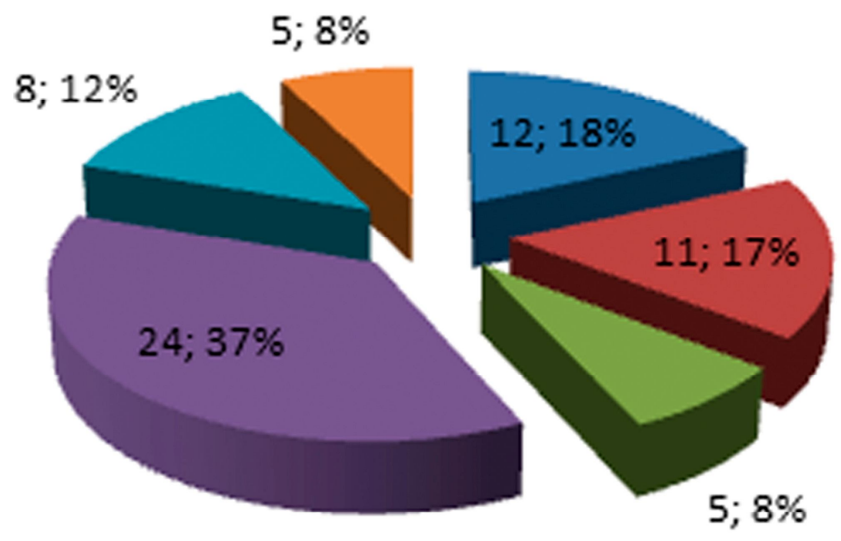

Гя 52-64

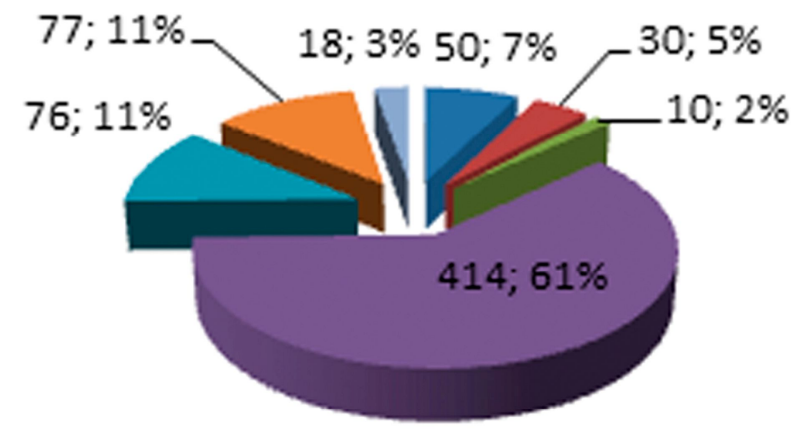

гя 1-60 무оглиняна

- Сіролощена i чорнолощена

Іонійська

口 Лiпна

Червонолакова
— Червоноглиняна

п Сіроглиняна

Сіролощена

Розписна

Кухонна

Ліпна

Червонолакова

Рис. 5. Діаграми заповнення керамікою господарських ям (ГЯ) (друга половина VII - початок VI ст. до н.е.). 


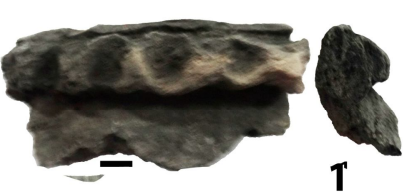

162-74
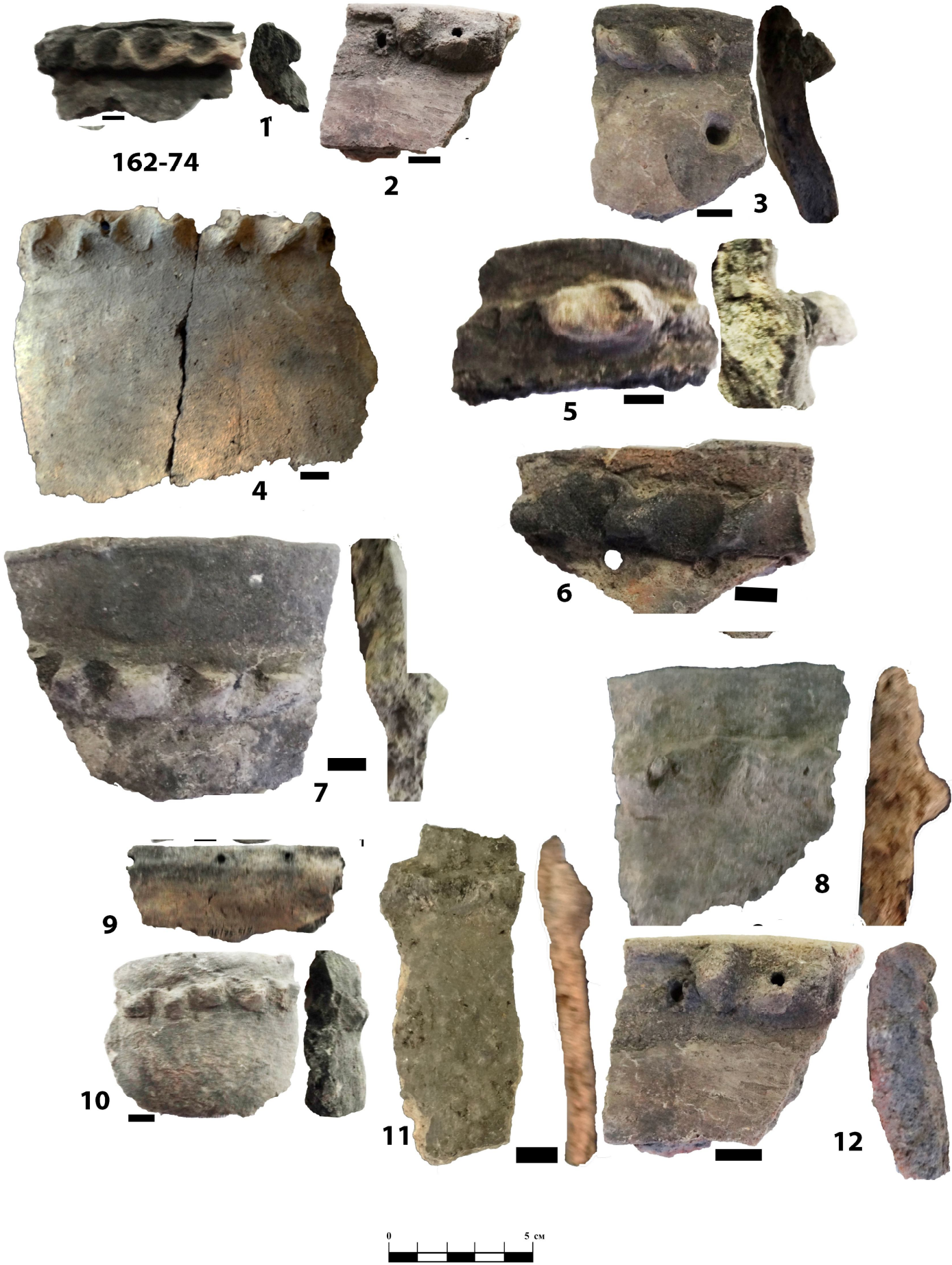

Рис. 6. Банкоподібні посудини (друга половина VII - початок VI ст. до н.е.): з наміченою шийкою (1-6); з прямим або скошеним горлом (7-12). 


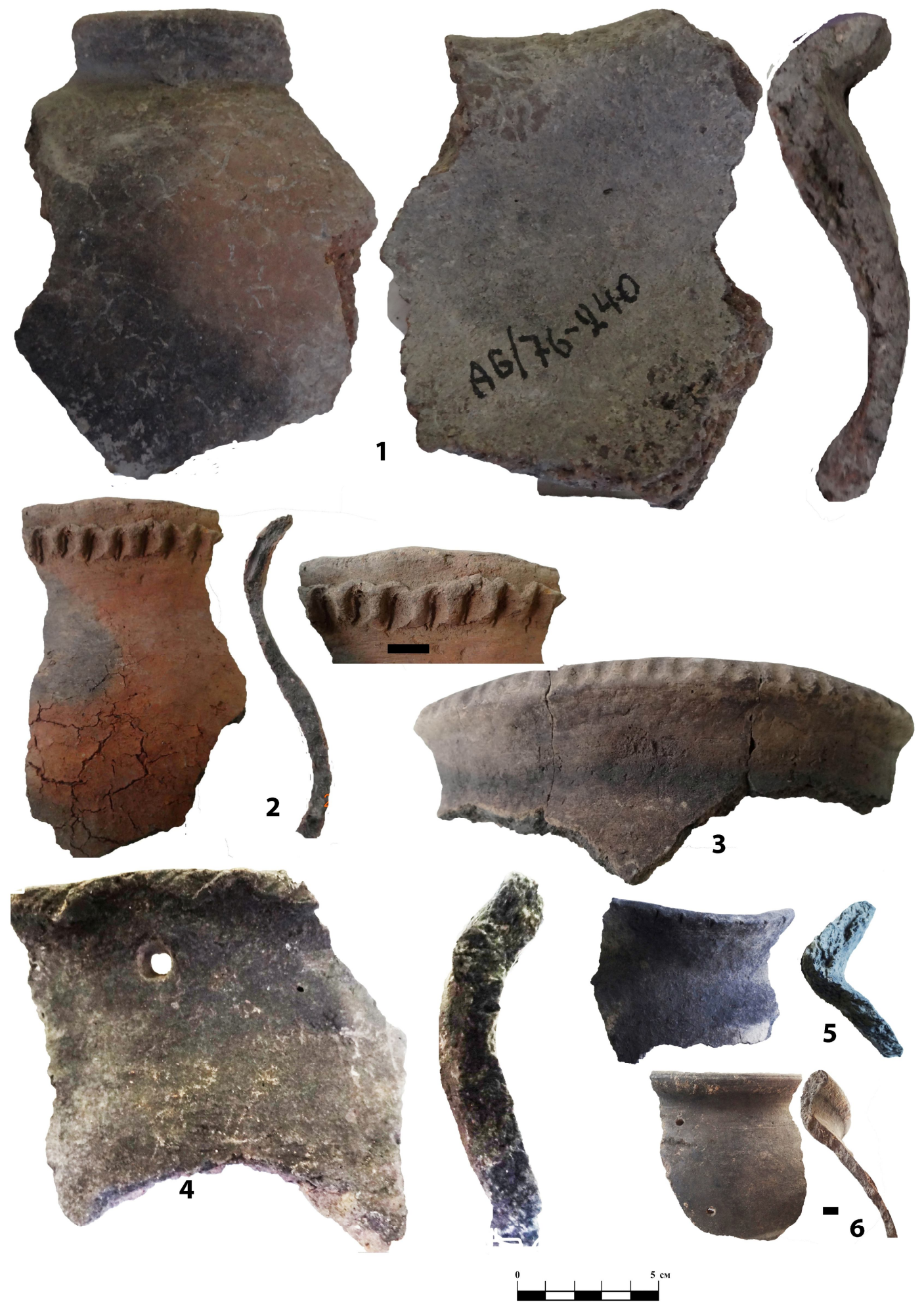

Рис. 7. Горщики: з дугоподібною шийкою (1-3); з горлом у вигляді розтрубу (4-6). 

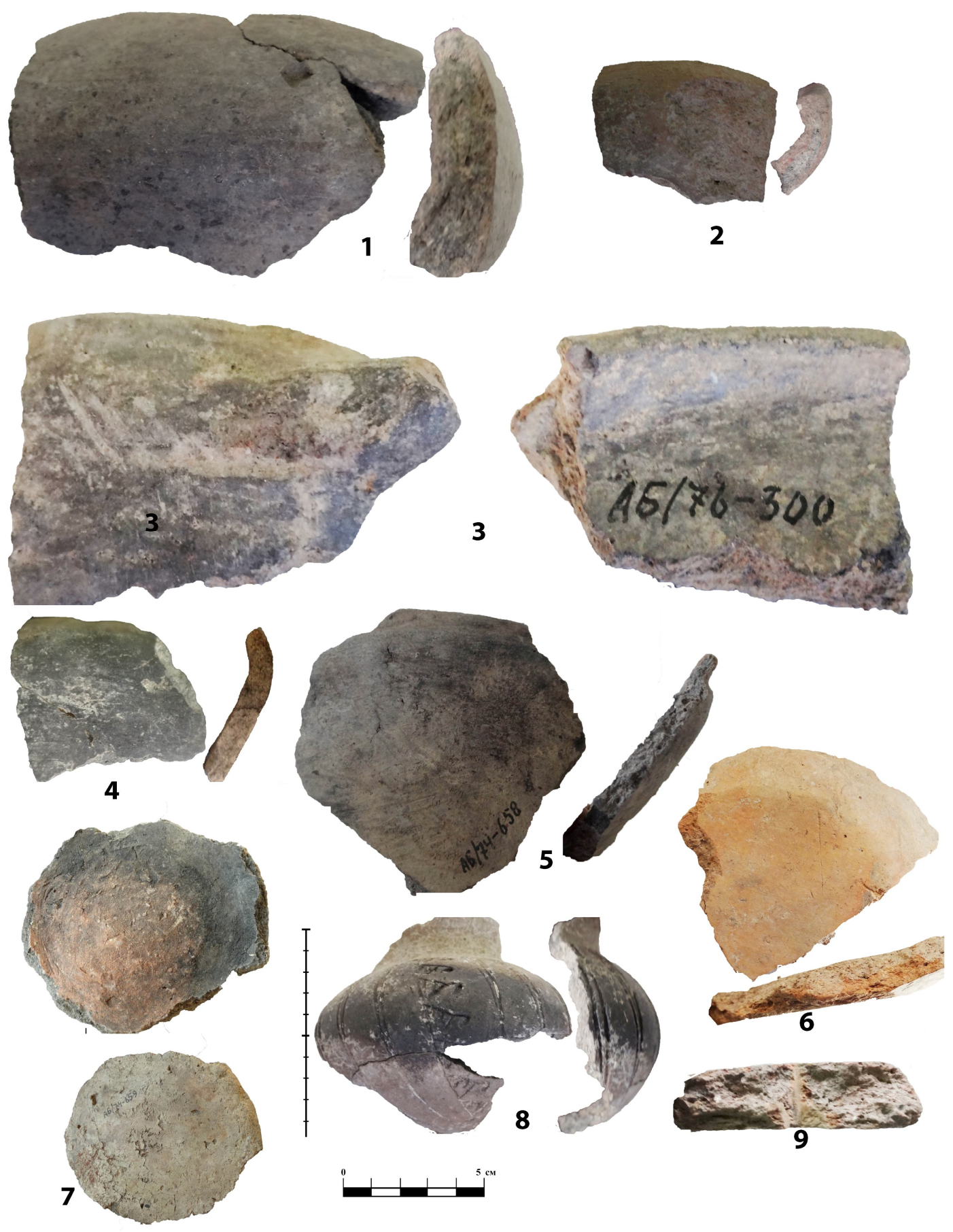

Рис. 8. Миски (1-5); дно лощеного кубка (6); світильник (7); кубок (8); плаский диск (9). 